\title{
CORRECTION
}

\section{Correction to: Commemorating the 30 Anniversary of the Americans with Disabilities Act}

\author{
Patricia A. Findley ${ }^{1}$. Douglas P. Gross ${ }^{2}$
}

Published online: 5 March 2021

(c) Springer Science+Business Media, LLC, part of Springer Nature 2021

\section{Correction to: Journal of Occupational Rehabilitation https://doi.org/10.1007/s10926-020-09949-0}

The editorial "Commemorating the 30th Anniversary of the American's with Disabilities Act" by Patricia Findley and Douglas P. Gross was inadvertently omitted from the special section "Americans with Disabilities Act 30" in the
December Issue (https://link.springer.com/journal/10926/ volumes-and-issues/30-4).

Publisher's Note Springer Nature remains neutral with regard to jurisdictional claims in published maps and institutional affiliations.

The original article can be found online at https://doi.org/10.1007/ s10926-020-09949-0.

Patricia A. Findley

pfindley@ssw.rutgers.edu

Douglas P. Gross

dgross@ualberta.ca

1 Rutgers School of Social Work, The State University of New Jersey, 120 Albany Street, Room 209, New Brunswick, NJ 08901, USA

2 University of Alberta, 2-50 Corbett Hall, Edmonton, AB T6G 2G4, Canada 